\title{
Menguji Akuntabilitas Anggota Dewan Perwakilan Rakyat Daerah Kabupaten Sumenep \\ Periode 2019-2024
}

\author{
Oleh : \\ Imam Hidayat ${ }^{1}$ \\ Fakultas Ilmu Sosial dan Ilmu Politik, Universitas Wiraraja \\ Email : imamhidayat@wiraraja.ac.id
}

\begin{abstract}
Accountability of the Members of the Regional Representative Council is a principle that must be fulfilled by the Sumenep Regency DPRD, as a basic criterion in providing performance reports of the main duties and functions of the Regional Representative Council of the Sumenep Regency. The purpose of this study provides important input for the performance of members of the Regional Parliament of Sumenep Regency so that researchers and readers really know the performance activities of the Sumenep Regency DPRD. This type of research uses descriptive and qualitatively discussed or analyzed which examines the performance accountability of members of the Sumenep Regency DPRD from the point of view expressed by (PIRAC, Public Interesest Research and Advance Center) regarding the principles of accountability including Indepedence, Non-Discrimination, Transparency, Transparency, Learning and Improvement, Independence. From the research results obtained from testing the accountability of the Sumenep Regency DPRD based on the focus of the study including the independence of the DPRD members who are still strongly intervened by party interests, non-discrimination still prioritizes the interests of the closest groups, Transparency needs to be increased so that there needs to be an understanding between the $D P R$ and the Public, Learning and Improvements need to be improved separately for the ability of HR performance of members of the Sumenep Regency DPRD, Independence needs high courage in deciding policies in the interests of the people of Sumenep Regency in general.
\end{abstract}

Keywords: Accountability of Sumenep Regency DPRD Members. 


\begin{abstract}
Abstrak
Akuntabilitas Anggota Dewan Perwakilan Rakyat Daerah merupakan prinsip yang harus dipenuhi oleh DPRD Kabupaten Sumenep, sebagai kriteria dasar dalam memberikan laporan kinerja dari tugas pokok dan fungsi Dewan Perwakilan Rakyat Daerah Kabupaten Sumenep.Tujuan dari penelitian ini memberikan masukan penting bagi kinerja anggota Dewan Perwakilan Rakyat Daerah Kabupaten Sumenep sehingga peneliti dan pembaca benar-benar mengetahui kegiatan kinerja DPRD Kabupaten Sumenep. Jenis penelitian ini menggunakan deskriptif dan dibahas atau dianalisa secara kualitatif yaitu menguji pertanggung jawaban kinerja anggota DPRD Kabupaten Sumenep dari sudut pandang yang dikemukakan oleh (PIRAC, Publik interesest reserch and advoncy center) tentang prinsipprinsip akuntabilitas meliputi Indepedensi, Non-Diskriminasi, Transparansi, Pembelajaran dan Perbaikan, Kemandirian. Dari hasil penelitian yang didapatkan dari menguji akuntabilitas DPRD Kabupaten Sumenep berdasarkan fokus penelitian diantaranya Indepedensi yang dimilki anggota DPRD masih kuat terintervensi oleh kepentingan partai, non-deskriminasi masih mengutamakan kepentingan kelompok terdekat, Transparansi perlu ditingkatkan sehingga perlu adanya pemahaman antara DPR dengan Publik, Pembelajaran dan Perbaaikan perlu ditingkatkan utnuk kemampuan kinerja SDM anggota DPRD Kabupaten Sumenep, Kemandirian perlu adanya keberanian yang tinggi dalam memutuskan kebijakan untuk kepentingan masyarakat Kabupaten Sumenep secara umum.
\end{abstract}

Kata Kunci : Akuntabilitas Anggota DPRD Kabupaten Sumenep. 


\section{PENDAHULUAN}

Setiap lima tahun sekali konstitusi mengamanahkan kepada pemerintah untuk melakukan pemilihan secara langsung dimana semua kelompok masyarakat yang memnuhi syarat sebagai pemilih untuk ikut aktif menentukan suaranya sebagai bukti bahwa demokrasi dan kedaulatan rakyat benar-benar terlaksana di Negara ini.

Salah satunya adalah dengan ikut aktif memilih wakil rakyat, sebagai pengganti mengurus keperluan rakyat, keperluan yang menyangkut kesejahteraan dan kenyamanan bernegara sehingga rakyat dipandang perlu mengutus wakil rakyatnya dalam memenuhi kepentingan hajat publik.

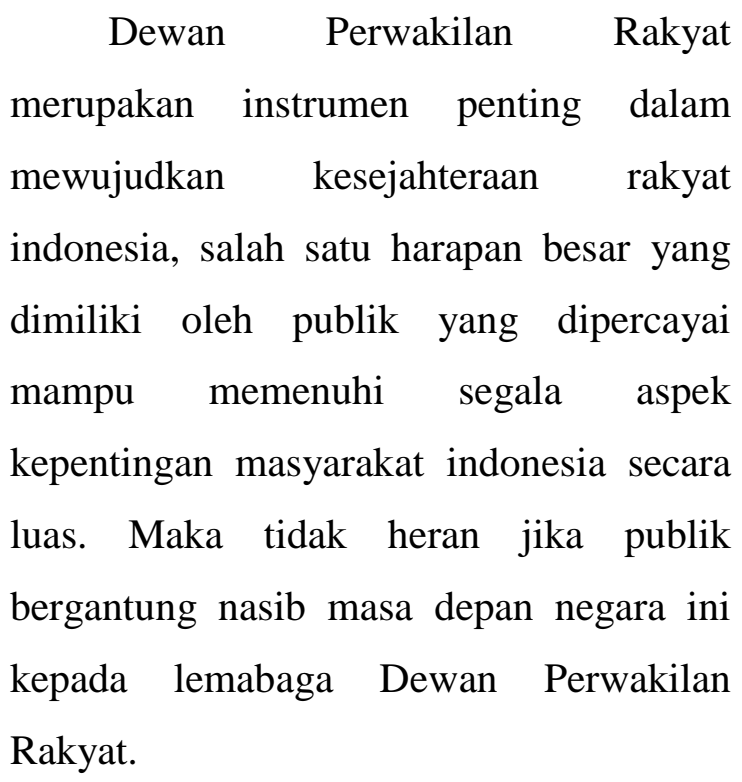

Tugas dan tanggung jawab Dewan Perwakilan Rakyat begitu mulia, untuk itu negara memberikan fasilitas yang menyangkut segala apa yang menjadi intrumen pendukung bagi DPR dalam merumuskan sistem dan regulasi terbaik bagi publik. Sampai saat ini pemerintah terus beruapaya memperbaiki kualitas pelaksanaan kinerja salah satunya adalah persoalan akuntabilitas dan transparansi. (Amin Rahmanurrasjid, 2008)

Dewan Perwakilan Rakyat memiliki tiga fungsi pokok kerja dalam rutinitas dan agenda kesehariannya, fungsi legeslasi merupakan tugas dan tanggung jawab DPR dalam konteks merumuskan undangundang berkenaan dengan tatanan sosial dalam kehidupan bermasyarakat yang luas, fungsi budgeting merupakan kewajiban DPR untuk merumuskan anggaran yang tepat untuk direalisasikan dalam rangka memenuhi kepentimngan dan kebutuhan publik, fungsi terakhir adalah sebagai controling merupakan tugas yang diberikan kepada Dewan Perwakilan Rakyat Daerah untuk mengontrol semua aktifitas pelayanan dan kinerja eksekutif dalam melayani masyarakat luas.

Maka sangat mengganjal jika Dewan Perwakilan Rakyat mengabaikan aspirasi publik, produk undang-undang yang masih lemah, tidak rasional dan masih minim sehingga menimbulkan reaksi publik demontrasi dan menyatakan kecewa terhadap kinerja Dewan Perwakilan Rakyat. Selanjutnya, Dewan Perwakilan Rakyat tidak optimal dalam mengolah keungan negara sebagai rencana belanja 
aparatur yang terkesan asal-asalan tanpa meilhat kebutuhan dan keutmaan anggaran tersebut. Atau, fungsi pengawasan Dewan Perwakilan Rakyat terhadap aktifitas yang dilakukan oleh para kepentingan terkesan melonggarkan sehingga hanya berpihak kepada sebagian kelompok. Dan parahnya masih banyak ditemui pada anggota Dewan Perwakilan Rakyat mengutamakan partainya ketimbang aspirasi publik sehingga tidak jarang ada perselisihan pendapat antara kelompok anggota DPR satu dengan kelompok lainnya atau mereka tidak mengerti soal petugas partai dan sebagai wakil rakyat.

Kinerja dari petugas publik harus mampu terukur dengan baik, dimulai dari perencanaan, implementasi, evaluasi dan rekomendasi merupakan satu rangkaian aktifitas program kerja yang perlu dikerjakan secara teratur dan sistematis sehingga apa yang menjadi catatan penting untuk dieavaluasi dapat diketahui kemudian sebagai pijakan dalam memperbaiki kearah yang lebih baik di masa selanjutnya. Untuk mencapai pemerintahan yang baik maka unsur pokok dari itu adalah akuntablitias, untuk pemerintah saat ini mengupayakan agar unsur tesebut benar-benar dipenuhi dalam kegiatan kinerja pejabat publik.

Kasus-kasus diatas juga bisa saja terjadi pada anggota Dewan Perwakilan
Rakyat Daerah di Kabupaten Sumenep, sehingga perlu ditegaskan lagi soal tugas dan tanggung jawabnya dalam memberikan kontribusi yang nyata bagi kemaslahatan masyarakat Kabupaten Sumnep. Maka dari penelitian ini penulis menguji pertanggung jawaban anggota DPRD Kabupaten sumenep dengan berpedoman pada teori-teori tentang prinsip-prinsip akuntablitias dalam Humanitarian Forum Indonesia (Public Interesrt Reserch and Advoncy Center. PIRAC,).

\section{TINJAUAN TEORITIS}

\section{A. Akuntabilitas}

Akuntabilitas merupakan usaha pokok kerja yang ditampilkan oleh lembaga publik dalam memberikan sebuah pertanggung jawaban dan keterangan sebenar-benarnya oleh badan hukum atau pimpinan institusi secara kolektif kepada pihak yang diberi tannggung jawab untuk memeriksa kinerja atau berani memberikan pertanggung jawaban sesuai dengan tugas pokok dan fungsinya kepada publik yang tujuan akhirnya adalah bermanfaat bagi kepentingan masyarakat umum. Selain itu akuntabilitas merupakan bentuk usaha maksimal yang dilakukan oleh pejabat publik berdasarkan kinerja 
melalui media pelaporan dalam institusi pemerintah. (Elvira Zeyn, 2011)

Mohammad dkk (2004, h 50) menjelaskan akuntabilitas memiliki 3 jenis macam yaitu:

1. Akuntabilitas Keuangan, merupakan pertanggung jawban yang meliputi laporan keuangan yang terdapat beberapa macmam, misalnya penerimaan/pendapatan, pengeluaran dan penyimpanan.

2. Akuntabilitas Manfaat, merupakan usaha sebagai bentuk pertanggung jawaban oleh pejabat publik yang mencakup soal tujuan, proses dan hasil sesuai dengan prosedur yang bermanfaat bagi publik dan memiliki luar efektivitas yang optimal.

3. Akuntablitas Prosedural, merupakan bentuk usaha untuk memberikan bentuk pertanggung jawaban berkenaan dengan regulasi, pedoman dan prosedur pelaksanaan yang mempertimbangkan moralitas, asas etika dan kepastian hukum. (Rahmi Fajri, 2015)

\section{B. Prinsip Akuntabilitas}

Hakikat dari akuntabilitas sendiri merupakan komitmen yang dimiliki oleh petugas publik yang dalam hal ini adalah DPRD Kabupaten Sumenep dalam rangka menjaga tugas dan fungsinya sebagai DPR untuk terus tanpa kompromi dan kekuatan intervensi internal kelompok sehingga hanya memilki tujuan yang satu yaitu mengurus segala kepentingdan dan kebutuhan publik secara menyeluruh, baik kelompok atas, bawah, kota atau pelosok desa.Untuk itu petanggung jawaban memiliki hasil akhir pada kepentingan publik dengan mengharapkan ada perubahan dari sisi kualitas kinerja dari pejabat publik.(Elgia Astuty, 2013)

Sikap akuntabiitas yang tinggi akan menghasilkan tranparansi terhadap kebijakan politik yang diambilnya sehingga publik juga mengetahui dengan jelas dan seksama sehingga publik ikut andil memberikan masukan dan kontribusi bagi kemajuan

kesejahteraan masyarakat secara luas. Seiring dengan berjalannya sistem otonomi daerah maka tuntutan akuntabilitas kinerja menjadi prisnip penting bagi otonom di Indonesia. (Wahyu setiawan, 2013)

Hal tersebut menjadi sangat urgen bagi aktifitas dan kinerja DPRD Kabupaten Sumenep, maka sesuai dengan pernyataan Humanitarian forum indonesia (PIRAC, Publik interesest 
reserch and advoncy center) menyebutkan tentang prinsip-prinsip akuntablitas sebagai berikut:

1. Indepedensi, dimulai dari pertama masuk kantor legeslatif sudah harus sadar bahwa anggota DPRD Kabupaten Sumenep bekerja untuk konstitusi bukan lagi sebagai petugas atau kader partai, sehingga ia berada di organisasi otonom pemerintahan yang bebas dari kepentingan kelompoknya dan tidak lagi ada intervensi husus dalam mengkawal kinerjanya sebagai anggota Dewan Perwakilan Rakyat.

2. Non-Diskriminasi, meraka sebagai anggota Dewan Perwakilan Rakyat tidak ada lagi keberpihakan kepada salah satu kelompok baik status sosial, agama, ras, suku dan budaya. Ia harus mampu memberikan kenyamanan bagi seluruh masyarakat yang luas tanpa terkecuali

3. Transparansi, bahwa anggota Dewan Perwakilan Rakyat sebagai penyambung dari kegelisahan rakyat harus benar-benar menyediakan informasi yang jelas dan akurat serta dapat dipertanggung jawabkan mengenai program kerja, pengelolaan anggaran pada Dewan Perwakilan Rakyat.

4. Pembelajaran dan Perbaikan, Anggota Dewan Perwakilan Rakyat tidak boleh antri kritik, ia harus selalu berbenah dan mengevaluasi terus berupaya untuk mencapai kerja yang optimal dan profesional

5. Kemandirian, tidak lagi bergantung pada pihak atau kelompok lainnya sehingga kebijakan yang akan diambil terkesan akan ada pesanan, maka anggota DPR harus memiliki sifat pertanggung jawaban dengan mandiri dan tidak selalu bergantung pada kelompok atau pihak yang tidak memilki kepentingan. (Tim Penyusun PAPBK, 2011).

\section{METODE PENELITIAN}

Dalam menyusun proposal penelitian ini, peneliti menggunakan pendekatan kualitatif, dengan mencermati kinerja dan pertanggung jawaban sebagai anggota Dewan Perwakilan Rakyat Daerah Kabupaten Sumenep lalu dilakukan beberapa analisa mengenai tentang prinsip-prinsip akuntabilitas dan memakai beberapa sumber dan materi yang terdapat dalam buku, data kualitati merupakan 
data-data yang bukan berbentuk angka (Sugiyono, 2006: 14).

Meilhat fenomina dan beberapa sumber informasi dari informan terkait pertanggung jawaban oleh anggota DPRD Kabupaten sumenep maka ditemukan fokus penelitian sesuai dengan materi yang disampakan oleh (PIRAC, Publik interesest reserch and advoncy center) tentang prinsip-prinsip akuntabilitas meliputi Indepedensi, Non-Diskriminasi, Transparansi, Pembelajaran dan Perbaikan, Kemandirian.

\section{HASIL DAN PEMBAHASAN}

\section{A. Indepedensi}

Sikap independensi ini menjadi jati diri DPR, sebab pada hakekatnya keterikatan anggota DPR dengan Parpolnya harus terus berkurang bahkan minim sebab dilembaga perwakilan rakyat Indonesia selayaknya tidak dikenal Lembaga Perwakilan Parpol untuk menjaga Lembaga Tinggi Negara ini tidak senantiasa diintervensi oleh kepentingankepentingan tertentu yang tidak berhubungan dengan kepentingan seluruh rakyat Indonesia dan tidak terkooptasi dengan persoalan-persoalan sebatas kekuasaan semata. Oleh karena itu setiap anggota DPR semestinya tidak lagi merangkap sebagai pengurus Parpol dan tidak merangkap jabatan sebagai Pejabat Publik atau Negara. Sistem yang menjaga independensi DPR harus terus dibangun dan diperkuat. Tetapi untuk menjaga agar tidak terjadinya peralihan kekuasaan dari pemerintah ke DPR maka harus pula diciptakan mekanisme keterlibatan rakyat melalui berbagai lembaga rakyat, lembagalembaga Adat. Segala aspirasi publik yang diperjuangkan oleh DPRD merupakan tugas besar yang harus bebas dari intervensi yang menghambat akan pelaksanaan keijakan kebutuhan publik..

Dilihat dengan adanya data yang di dapat dari hasil penelitian bahwasanya Akuntabilitas Anggota Dewan Perwakilan Rakyat Daerah Kabupaten Sumenep hal ini dalam mengimplementasikan indepedensi dari anggota DPRD di lakukan secara kongrehensif yaitu dengan mengkomunikasikan kepada seluruh anggota DPRD menghindari pertemuan rahasia selain di rapat paripurna dengan kelompok atau pihak manapun

Namun dengan demikian berdasarkan wawancara dan observasi dengan Komisi-Komisi dan Faraksi-Fraksi di lingkungan kantor DPRD Kabupaten Sumenep tentang indepedensinya sebagai pemerintah legeslasi, terkadang berada dalam posisi dilematis karena berbagai pihak melakukan pendekatan persuasuif di jam lain kantor. Untuk itu demi terjaganya indepedensi dari anggota DPRD kabupaten sumenep harus tegas dalam mengambil 
keputusan dengan mengutamakan kepentingan publik. Tegas berarti selalu siap dengan resiko demi memperjuangkan amanat rakyat. Tegas membutuhkan disiplin sebagai salah satu pilarnya, salah satu dari cerminan disiplin itu ialah setiap anggota DPR harus punya schedule yang tertulis tentang apa yang ia lakukan selama masa tugasnya. Schedule yang terbuka dan dapat diujinilai oleh rakyat. Tidak ada alasan untuk menunda perumusan dan pengesahan UU yang sangat dibutuhkan rakyat.

Tegas tidak sama dengan ngotot. Tegas berarti tidak goyah dari prinsipprinsip mementingkan dan mengutamakan kepentingan dan kehendak rakyat karena kepentingan dan kehendak rakyat itulah yang menjadi sumber hukum,sumber kebenaran seorang anggota DPR dalam berargumentasi.

\section{B. Non-Diskriminasi}

Merupakan tindakan DPRD yang itidak membedakan antar sesama publik. Bahwa setiap Rakyat berhak mengajukan pendapat dan diperjuangkan kebutuhannya karena pada dasarnya DPRD merupakan wakil rakyat yang senantiasa membantu rakyat dalam setiap kesulitannya hususnya untuk golongan masyarkat lemah.

Kita ketahui bersama bahwa bangsa indonesia bermacam macam kemampua rakyatnya, ada golongan atas, menengah dan bawah.Non diskriminasi yang terdapat dalam diri anggota DPRD juga harus diterapkan pada semua golongan masyarakat, agar masyarkat dapat puas dengan hadirnya DPRD kabupaten Sumenep.

Dengan tidak membedakan antar golongan masyarkat maka DPRD akan semakin maksimal dalam proses kinerjanya sebagai perwakilan rakyat, Selain DPRD harus mensetarakan semua rakyatnya DPRD juga diharapkan mampu melindungi masyarkatnya dari luar yang bersifat tidak menguntungnkan bagi rakyatnya.

Prinsip Non Diskriminasi harus dimiliki oleh anggota DPRD karena dalam setiap tugasnya DPRD akan teruji profesionalitasnya sebagai wakil rakyat, segala kepentingan kelompok. Individu, bukanlah kepentingan yang paling utama yang harus diperjuangkan,karena kepentingan masyarkat secara menyeluruh merupakan kebijakan yang paling utama dalam proses program kerjanya DPRD.

Dengan dmikian sebagaimana yang telah kami lakukan observasi di kantor DPRD Kabupaten Sumenep. Masyarakat dan DPRD harus mdapat menjadi patner sejati artinaya masayarkat juga harus membantu meringankan beban tugas DPRD dalam mewujudkan Good 
Governace dengan menyetarakan semua golongan masyarakat.

\section{Transparansi}

Sukses dan tidaknya suatu implementasi kebijakan publik tidak hanya terwujud karena profesionalisme dari anggota DPRD dalam menyetarakan semua golongan, namun kebijakan bisa berhasil secara maksimal karena suatu tindakan dan karakteristik dari seorang pimpinan karena pimpinan merupakan ujung tombak dari suatu organisasi.

Dari data yang di dapat, transparansi merupakan kunci yang uatama dalam proses dari sebuah penyelenggara kepentingan rakyat, karena transparansi akan membantu penyediaan informasi dan komunikasi timbal balik antara DPRD dan Masyarakat.

DPRD Kabupaten Sumenep perlu proaktif memberikan informasi lengkap tentang kebijakan dan layanan yang disediakannya kepada masyarakat. Dengan menyiapkan kebijakan yang jelas tentang cara mendapatkan informasi. Kebijakan ini akan memperjelas bentuk informasi yang dapat diakses masyarakat ataupun bentuk informasi yang bersifat rahasia.

$\begin{array}{ccr}\text { Intrumen } & \text { pendukung dari } \\ \text { terselenggaranya } & \text { transparansi adalah }\end{array}$
fasilitas database dan sarana informasi dan komunikasi dan petunjuk penyebarluasan produk-produk dan informasi yang ada di penyelenggara DPRD kabupaten Sumenep sedangkan Intrumen dasar dari transparan adalah peraturan yang menjamin hak untuk mendapatkan informasi, sedangkan Untuk itu perlu adanya perda transparansi sebagai produk hukum yang memberikan jaminan untuk mengatur tentang hak memperoleh akses dan penyebar luasan informasi kepada publik.

Keberhasilan kepemimpinan DPRD Kabupaten Sumenep dapat di lihat dengan adanya peningkatan pencapaian target dari tahun ke tahun baik secara tingkat kepuasan masyarakat dalam menerima informasi secara terbuka ataupun penggunaan media tentang DPRD yang dapat dikunsumsi oleh semua kalangan.

\section{Pembelajaran dan Perbaikan}

Profesionalitas dari anggota DPRD sangat dibutuhkan, karena publik sangat butu wakil rakyat yang agresif dalam segala bidang termasuk berkualitas dalm memahami pesoalan - persolan yang ada.

Dari data yang di dapat dari penelitian kantor DPRD kabupaten Sumenep sangatlah menyadari kemampuan dari DPRD sangatlah pentingn bagi kemajuan lembaganya karena legeslatif di tuntut mampu proporsional dalam menghadapi bidangnya.

Ada banyak hal yang dilkukan untuk memperbaiki kemaampuan anggota DPRD kabupaten sumenep oleh ketua Dewan, salah satunya melalui program studi 
banding dengan DPRD kota lain, hal ini membantu agar DPRD kabupaten sumenep memilki refrensi dalam kinerjanya.

Selain itu program diklat pengembangan Sumeber daya manusia (SDM) yang miliki oleh anggota DPRD harus selalu diasah dalam menghadapi kemajemukan persoalan, sehingga wakil rakyat saat turun kelapangan terbiasa dengan menghadapi masalah masalah yang berat.

Namun yang lebih penting adalah kesadaran yang selalu timbul atas inisiatif diri sendiri, melakukan perbaikanperbaikan atas apa yang telah dilakukannya selama menjadi anggota DPRD. Sehingga akan menjadi acuan penting dalam menghadapi segala persoalan yang akan datang.

\section{E. Kemandirian}

Implememntasi dari kemampuan DPRD dalam meperjuangkan aspirasi masayarakat dapat dilihat dari pengambilan keputusannya apakah ia masi tergantntung pada pihak luar atau bisa berdikari sendiri. Disinilah DPRD dituntut memiliki bekal yang memadai, salah satunya dengan bekal percaya diri dari hasil pelatihan dan tantangan - tantangan yang dihadapinya selama di DPRD dapat menjadi bekal mandiri yang hingga tidak bergantung pada kemampuan pihak lainnya.
Dari hasil data dan observasi yang telah dilaksanakan parpol dapat mempengaruhi atas prinsip mandiri yang dimiliki oleh anggota DPRD Kabupaten sumenep, kelompok parpol dengan alat kelengkapannya dan kemampuan sumber daya manusia yang dimilikinya dapat masuk mengintervensi kader-kadernya yang ada didalam struktural DPRD, sehingga parpol mempunyai otoritas penuh terhadap kadernya untuk melancarkan tujuan dari parpolnya. Dengan demikian DPRD harus mempunyai tingkat kesadaran yang tinggi bahwa selain menjadi kader Parpol, anggota DPRD Kabupaten Sumenep mempunyai tugas penting yaitu mensejahterakan dan memenuhi keinginan rakyat.

Maka Dewan Perwakilan Rakyat Daerah Kabupaten Sumenep harus mempunyai sikap pendirian yang mandiri, mandiri dari berbagai tantangan yang akan dihadapinya. Kemampuan sikap madiri sangatlah penting karena prinsip mandiri yang dimiliki oleh DPRD merupakan alat untuk menjaga intervensi dari luar yang hendak ingin menguasai atas kepentingan masyarakat.

\section{PENUTUP}

Sikap independen yang dimiliki oleh anggota DPRD Kabupaten Sumenep tergolong rendah, hal ini disebabkan adanya intervensi dari pihak internal partai 
atau ekternal pertai, yang meyebabkan setiap rapat sering berujung dengan ketidak sepahaman antar anggota DPRD yang sama-sama kokoh dengan pendapatnya masing-masing kemudian DPRD Kabupten sumenep harus lebih memperhatikan sama rata dalam pengambilan kebijakannya, karena anngota DPRD tersebut masih mendahulukan kepentingan orang terdekatnya, maka Non-Diskriminasi yang menjadi rujukan dalam kinerja DPRD perlu dievaluasi dari masing-masing anggota DPRD Kabupaten Sumenep, selain itu DPRD Kabupaten Sumenep kurang tranparan dalam penyampaian informasi dalam agenda kerja DPRD selama 1 periode, sehingga pubik terjadi miskomunikasi dengan pihak DPRD Kabupaten Sumenep dan dalam hal Pembelajaran dan perbaikan DPRD kabupaten sumenep, masih tergolong lemah, karena masih banyaknya anggota DPRD Kabupaten Sumenep yang gagap tekhnologi dan rendahnya pengetahuan cara pemakaian bahasa yang formal dan baku dan Sikap mandiri harus dimiliki oleh anggota DPRD kabupaten Sumenep, karena Anggota DPRD masi bergantung pada kepentingan partainya, mengabaikan kepentingan umum demi menagnya partai kelompoknya dari partai oposisinya.

Anggota DPRD Kabupaten Sumenep perlu adanya kesadaran untuk saling menghargai pendpat anggota DPRD yang bukan dari partainya, sama- sama mengedepankan toleransi pendpatnya, tidak ter-intervensi dari pihak internal atau ekternal sehingga kenyamanan dan kepercayaan antar anggota DPRD dapat tercipta dengan utuh kemudian Anggota DPRD Kabupaten Sumenep paling tidaknya melakukan pertemuan secara terus menerus samapai anggota DPRD tersebut memiliki sikap peduli kepada seluruh warga kabupaten sumenep tanpa mengedapankan yang satu pihak dan DPRD Kabupaten Sumenep perlu melakukan trobosan baru untuk menyampaikan segala informasi, agar DPRD benar-benar terasa transparansinya di publik dan tidak akan ada informasi yang terpotong, hingga publik juga tidak terjadi mis komunikasi dengan Anggota DPRD Kanupaten Sumenep, Menyediakan segala sarana agar masyarkat dapat menyampaikan keinginannya dengan mudah, danUntuk memperoleh hasil yang lebih maksimal perlu adanya komunikasi secara intensif dengan masyarakat agar Lebih intensif dalam mengadakan program pengembangan dan pelatihan SDM Anggota DPRD agar profesionalitasdari DPRD kabupaten Sumenep semakin bisa diandalkan, selan itu Anggota DPRD Kabupaten Sumenep Perlu memiliki sikap keberanian diri dalam mengambil keputusan, tampa mepertimbangkan 
keinginan parpolnya, kelompok, tokoh, dan pemangku kepentingan lainnya.

\section{DAFTAR PUSTAKA}

Astuty Elgia. (2013). Akuntabilitas Pemerintah Desa Dalam Pengelolaan Anggaran Pendapatan Dan Belanja Desa (Apbdes) (Studi Pada Alokasi Dana Desa Tahun Anggaran 2011 Di Desa Sareng Kecamatan Geger Kabupaten Madiun), Universitas Negeri Surabaya,

Fajri Rahmi dkk. (2015). Akuntabilitas pemerintah desa pada pengelolaan alokasi dana desa (ADD). (studi pada kantor desa ketindan, kecamatan lawang, kabupaten malang), Jurusan Administrasi Publik, Fakultas Ilmu Administrasi, Universitas Brawijaya, Malang Jurnal Administrasi Publik (JAP) Vol. 3, No. 7.

Kusumaningrum Indraswari. (2010).

Pengaruh Kejelasan Sasaran Anggaran, Pengendalian Akuntansi Dan Sistem Pelaporan Terhadap Akuntabilitas Kinerja Instansi Pemerintah Provinsi Jawa Tengah Universitas Diponegoro.
Rahmanurrasjid Amin. (2008).

Akuntabilitas Dan Transparansi

Dalam Pertanggungjawaban

Pemerintah Daerah Untuk

Mewujudkan Pemerintahan Yang

Baik Di Daerah (Studi Di

Kabupaten Kebumen). Program

Magister Ilmu Hukum Program

Pasca Sarjana Universitas

Diponegoro Semarang 2008.

Setiawan Wahyu. (2011). Pengaruh

Akuntabilitas Laporan Keuangan

Pemerintah Daerah (Lkpd)

Terhadap Tingkat Korupsi

Pemerintah Daerah Di Indonesia.

Universitas Diponegoro.

Sugiyono. (2008). Metode Penelitian Pendidikan Pendekatan Kuantitatif, Kualitatif, dan R\&D. Bandung.

Tim Penyusun PAPBK. (2011). (Pedoman Akuntabilitas Pengelolaan Bantuan Kemanusiaan), Pedoman akuntabilitas pengelolaan bantuan kemanusiaan di indonesia. Jakarta: PIRAMEDIA.

Zeyn Elvira. (2011). Pengaruh good governance dan standar akuntansi pemerintahan terhadap akuntabilitas keuangan dengan komitmen organisasi sebagai pemoderasi. (Universitas Pasundan Bandung, Jawa Barat) JRAK 1,1 
Vol 15, nomor I, Juni 2020

Jurnal Reviu Akuntansi dan

Keuangan ISSN: 2088-0685. 